\title{
Prenatal Development of Metacarpus and Metatarsus of Cattle
}

\author{
O. ŠTĚRBA
}

University of Veterinary and Pharmaceutical Sciences, Brno, Czech Republic

Received March 4, 2004

Accepted October 26, 2004

\begin{abstract}
Štěrba O.: Prenatal Development of Metacarpus and Metatarsus of Cattle. Acta Vet Brno 2004, 73: 405-412.

In the autopodium of the thoracic limb of cattle, os metacarpale III et IV is the most robust bone; in the corresponding part of the pelvic limb it is os metatarsale III et IV. These bones develop through the fusion of initially independent rudiments that become independently ossified. The prenatal development and ossification of these bones was studied in fixed cattle fetuses between 60 days of ontogeny (DO) and $260 \mathrm{DO}$ (the $9^{\text {th }}$ month of intrauterine development) of estimated age. Ossified sections of the diaphyses and epiphyses of the individual bones were measured in longitudinal sections through the autopodia. Our study has confirmed the observations of earlier authors concerning the onset and process of metapodium ossification. In cattle, ossification starts around the $60^{\text {th }}$ day DO (CS 7) with the development of periostal bone collars on metapodium III and IV lying next to each other. At first the ossified parts of the metacarpus and metatarsus are equal in length; from the $95^{\text {th }}$ DO (CS 9) the ossified parts of the metatarsus are longer than those of the metacarpus. Thereafter the metatarsus is longer than the metacarpus throughout the animal's life. The rudiments of the two bones of the metapodium (III and IV) are separated until the end of the $8^{\text {th }}$ month of intrauterine life, whereupon they are connected with a synostosis. The distal epiphyses become ossified starting with the end of the $7^{\text {th }}$ month of intrauterine life (CS 11). Observations made in two older fetuses $(600 \mathrm{~mm}$ CRL = Crown-Rump-Lenght, aged about 220 days; and 820 $\mathrm{mm}$ CRL, aged about 260 days) supplement the available literary data on the process of ossification and the dimensions of the ossified parts of diaphyses and epiphyses of the metacarpal and metatarsal bones.
\end{abstract}

Cattle, metacarpus, metatarsus, ossification

The study of the ontogeny of limb skeleton is an interesting topic of evolutionary morphology. In cattle, the study of metapodium development sheds more light on the phylogenetic development of limbs in specialised ruminant artiodactyls, as already pointed out by Rosenberg (1873). First, there is the question of the change of mesaxonic to paraxonic limbs when the limb axis has moved between toes III and IV; the next question is the successive reduction of the peripheral limb rays, i.e., rays I, II, and V. At present it is generally accepted that the reduction will first affect ray I, i.e. autopodium I, followed by the reduction of autopodia II and V, the order being not stated (II followed by V, or vice versa), this reduction having reached different degrees in the metapodia and acropodia of different taxons. The reduction either affected the distal parts of their metapodia, as in Plesiometacarpalia, or their proximal ones, as in Telemetacarpalia.

In the course of their ontogeny the metapodium bones first appear as a mesenchymatic condensation, later changing, as an interim degree, to cartilaginous models and finally to the osseous skeleton.

The development of metapodium bones in mammals showing reduced numbers of autopodium rays was studied as early as by Rosenberg (1873) and Mettam (1894). In transversal sections through the embryonic metacarpus and metatarsus of ruminants, they found the presence of four cartilaginous rudiments of metacarpus and metatarsus II to V, of which II and V are much thinner than III and IV. 
In embryos CRL 30 and $42 \mathrm{~mm}$, Petersen (1922) found cartilaginous models of autopodia, the major metacarpus and metatarsus being equal in length (4 and $5 \mathrm{~mm}$ respectively). From embryo CRL $50 \mathrm{~mm}$ onwards the metatarsi begin to be longer ( 6 and 7 $\mathrm{mm}$ ). In a fetus CRL $66 \mathrm{~mm}$ the author observed perichondral ossification of the diaphyses of metapodia III and IV, while that of the metapodia II and V was somewhat delayed. The metatarsi were longer $(11 \mathrm{~mm})$ than the metacarpi $(10 \mathrm{~mm})$. In fetuses CRL $92 \mathrm{~mm}$ and 95 $\mathrm{mm}$ all four metacarpi and metatarsi showed ossification, as confirmed by staining with alizarin red. The main metacarpi were $17 \mathrm{~mm}$, the metatarsi $18 \mathrm{~mm}$ long. These observations were confirmed by Martin (1912) in a fetus CRL $100 \mathrm{~mm}$. Fetuses CRL 115 and $125 \mathrm{~mm}$ show successive reduction of metacarpus and metatarsus II and V. Metacarpus II is only preserved in its distal section, metacarpus $\mathrm{V}$ divides into a proximal and a distal part. Metatarsus II has been completely resorbed, and only the proximal part remains of metatarsus V. In a fetus CRL $135 \mathrm{~mm}$ only the proximal part of metacarpus $\mathrm{V}$ has been preserved, ossifying in the proximal direction, whereas metacarpus II, metatarsus II and metatarsus V have disappeared. The main metacarpi are $28 \mathrm{~mm}$, the metatarsi $34 \mathrm{~mm}$ in length. A fetus CRL $420 \mathrm{~mm}$ (178 DO) already shows advanced ossification, its metacarpi III and IV being $47 \mathrm{~mm}$, metatarsi III and IV $51 \mathrm{~mm}$ long. Its metacarpus V is $7 \mathrm{~mm}$ long.

Küpfer and Schinz (1923) stated that the bones of the metapodium would develop from an initially five-rayed prechondral rudiment. The onset of ossification of diaphyses III and IV of the metapodium was demonstrated by these authors using the x-ray method in fetuses in the 9th week of intrauterine development (i.e. 57-63 DO) at CRL $82 \mathrm{~mm}$.

Using the same method, Gjesdal (1969) also demonstrated the onsets of ossification of metacarpi and metatarsi III and IV in fetuses of various cattle breeds at the age of 61-65 DO, i.e. two months, when the ossified diaphyses were $2 \mathrm{~mm}$ long. From the age of 76-80 DO to 96-100 DO onwards the metatarsus is invariably longer by $1 \mathrm{~mm}$ (10 and $11 \mathrm{~mm}$ respectively); from the age of 101-105 DO to 131-135 DO this difference increases up to $3 \mathrm{~mm}$ (23 vs. $26 \mathrm{~mm})$, and at the age of 136-140 DO the difference is $6 \mathrm{~mm}(24 \mathrm{vs} .30 \mathrm{~mm})$.

In the distal epiphysis, the presence of ossification centres can be demonstrated from the 7th month of intrauterine development (fetus $727 \mathrm{~mm}$ ) (Küpfer and Schinz 1923; Gjesdal 1969). Ossification continues in the diaphysis and distal epiphysis, still divided by a cartilaginous epiphysal plate; according to Kolda (1936), this plate becomes ossified at the age of 2-2.5 years, thus causing the epiphysis to fuse with the diaphysis. Using the $\mathrm{x}$-ray method and staining with alizarin red, Červený (1980) still found remains of an epiphysal cartilage in the metapodium of a bull 20 months of age.

According to Kolda (1936), in the metapodium of newborns it is still possible to separate the two initially independent bones (III and V). Küpfer and Schinz (1923) observed in their x-ray photographs that starting from 9 weeks of age (about 65 DO, CRL $82 \mathrm{~mm}$ ) until 6 months of intrauterine development (CRL $520 \mathrm{~mm}$ ), the ossified diaphyses of metapodia III and IV are still independent. In fetuses CRL 570 and $580 \mathrm{~mm}$ from the same month, the ossified diaphyses are in close contact, the same as in a fetus CRL $727 \mathrm{~mm}$ (end of the 7th month) where even the distal epiphyses begin to be ossified.

Regli (1963) states that the osseous connection between metapodia III and IV begins developing in the proximal-distal direction from $200 \mathrm{DO}$ onwards, to end around the $210^{\text {th }}$ day. The epiphyses become fused at the age of 2.5-3 years.

The prenatal development and growth of the skeleton of cattle autopodium was also studied by Červený $(1983,1985 a, 1985 b)$ and Červený and Páral (1994) who discussed the development of sesamoid bones which are parts of the skeleton of the autopodium. Using dissection, x-ray imaging, sections stained with alizarin red, and macerated material, the authors showed the time sequence of development of ossification centres of these bones, their morphological characteristics as well as sex-dependent differences. 


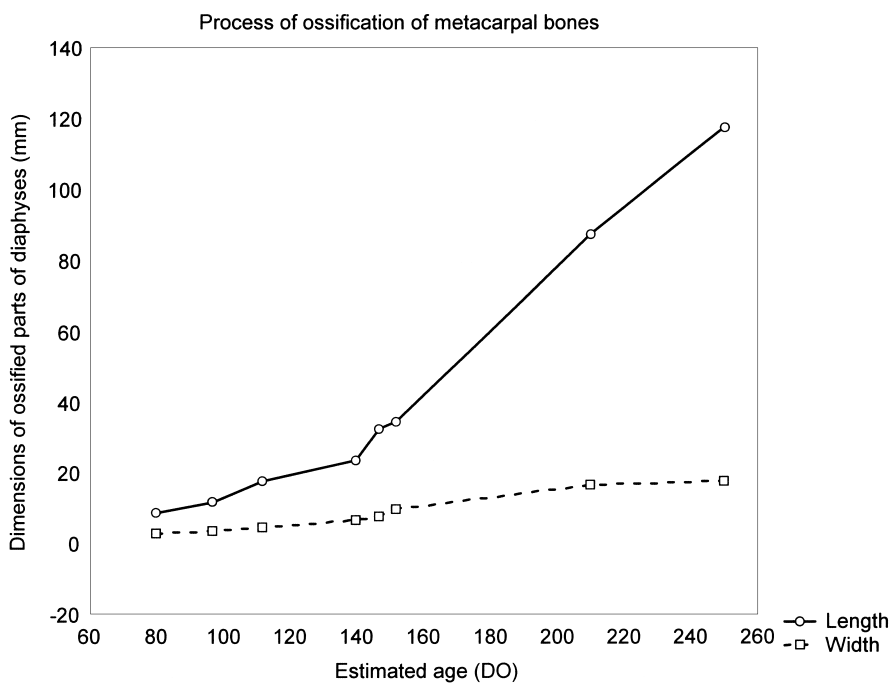

Fig. 1. Process of ossification of metacarpal bones. Solid line - length; dotted line - width. Correlation of two variables.

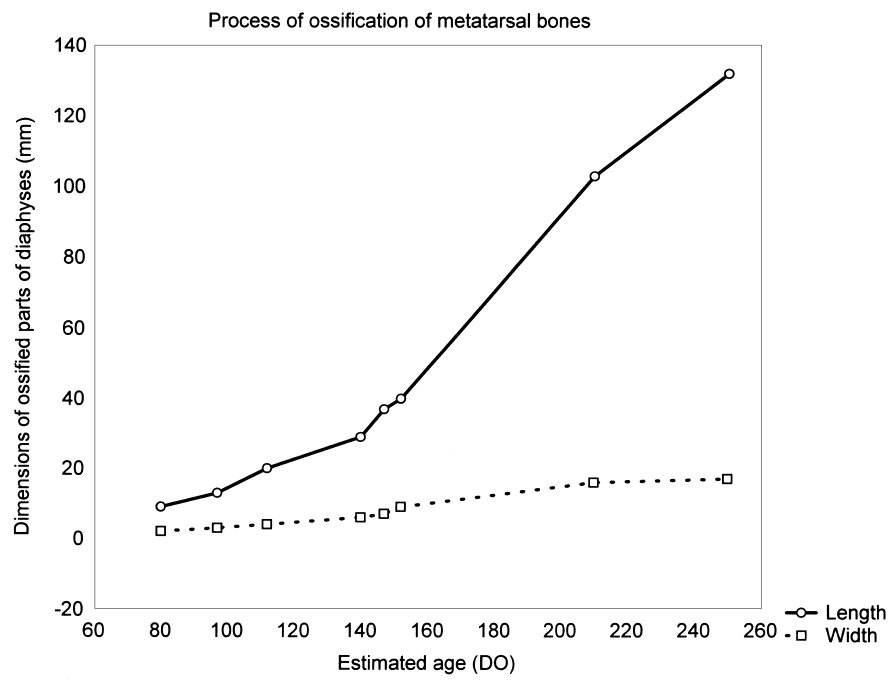

Fig. 2. Process of ossification of metatarsal bones. Solid line - length; dotted line - width. Correlation of two variables.

To create a complete idea of the developing skeleton, Páral and Míšek (1994) described the mineralization process of the bovine metatarsus during the period from 240 to $280 \mathrm{DO}$. They demonstrated a general increase in the ash content of the bone tissue and an increase in the levels of $\mathrm{Ca}, \mathrm{P}$, and $\mathrm{Mg}$ in the growth plate in the course of the study period.

The available literary sources, however, do not provide sufficient information on the ossification process, i.e., the sizes of the ossified sections of the metapodium diaphyses and epiphyses in more advanced fetuses before parturition. 


\section{Materials and Methods}

Earlier studies of the ontogeny of the autopodium skeleton employed the method of preparing microscopic slides and their subsequent staining (see Rosenberg 1873; Mett am 1894), which is time-consuming and requires much material. The development of $\mathrm{x}$-ray technique naturally lead to the introduction of this technique into the present branch of science (see Küpfer and Schinz 1923; Regli 1963; Červený et al. 1987 and many others). Another method used here was the imaging of the ossified sections of whole bones or their macroscopic sections stained with alizarin red. Having obtained good experience in imaging the advancing ossification as well as in staining whole fetuses, we have employed this method in the present study.

The present paper is based on fixed fetuses from the collections of the Department of Anatomy, Histology and Embryology, Faculty of Veterinary Medicine of the Veterinary and Pharmaceutical University in Brno. By their CRL and external characters the fetuses were classified in comparable developmental stages (Comparable Stages, $\mathrm{CS}$ ), and their ontogenetic age (Estimated Age, EA) on days of ontogeny (DO) was determined using the following table (see Št ěrba 1987, 1995 for particulars).

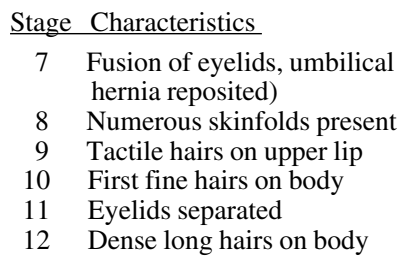

\begin{tabular}{rr} 
CRL, mm & EA - DO \\
\hline $50-70$ & $56-65$ \\
$80-120$ & $75-90$ \\
$130-250$ & $95-120$ \\
$250-380$ & $140-215$ \\
$390-470$ & $160-173$ \\
$560-850$ & $210-270$
\end{tabular}

Autopodia (left) removed from fixed fetuses were longitudinally cut with a scalpel along the lateral-medial plane, so that each bone (or bone rudiment) was divided into a dorsal and a palmar half. The bones of smallersized fetuses were stained with alizarin red and subsequently cleared, using the modification of Červený (1971). In fetuses 210 DO and older the differentiation method of staining bone sections with alizarin red was used (Červený 1979). The dimensions of the ossified sections of bone rudiments were measured with a calliper rule.

\section{Results}

The following facts were observed on the fetal autopodia stained with alizarin red and subsequently cleared (Plate I, Figs 3, 4):

Fetus CRL $=68 \mathrm{~mm}$, age about $60 \mathrm{DO}, \mathrm{W}=14 \mathrm{~g}$, CS 7 (No. 21/1): No signs of ossification were safely demonstrated in the cartilaginous rudiments of metapodia.

Fetus CRL $=120 \mathrm{~mm}$, age about 80 DO, W = 76 g, CS 8 (No. 68/4): The cartilaginous rudiments of metapodia show ossifying diaphyses, with a distinct connective tissue between them. The ossified sections of os metacarpale III et IV are $9 \mathrm{~mm}$ long, both diaphyses being $3 \mathrm{~mm}$ wide (Fig. 1). The ossified sections of of metacarpale III et IV are also $9 \mathrm{~mm}$ long, the diaphyses are $2 \mathrm{~mm}$ wide. No medullar cavities can be discerned. The distal epiphyses are still cartilaginous; ossification centres are already visible in digital phalanxes.

Fetus CRL = 173 mm, age about 95-100 DO, W = 268 g, CS 9 (No. 29/2): Rudimentary diaphyses undergo ossification. The ossified sections of ossa metacarpalia III et IV are 12 $\mathrm{mm}$ long and $4 \mathrm{~mm}$ wide; those of ossa metatarsalia III et IV are $13 \mathrm{~mm}$ long and $3 \mathrm{~mm}$ wide. The ossified sections are independent, separated by a thin connective strip; no medullar cavities were observed. The distal epiphyses are still cartilaginous.

Fetus CRL = $222 \mathrm{~mm}$, age about 112 DO, W = 564 g, CS 9 (No. 122/10): The ossified sections of diaphyses of metacarpals III and IV are $18 \mathrm{~mm}$ long and $5 \mathrm{~mm}$ wide, those of metatarsals III and IV are $20 \mathrm{~mm}$ long and $4 \mathrm{~mm}$ wide. The bones are still independent, separated by a thin connective strip; the diaphyses show developing medullar cavities. The whole epiphyses are still cartilaginous all over.

Fetus CRL $=270 \mathrm{~mm}$, age about 125 DO, W = 1092 g, CS 10-11? (No. 120/10): The ossified sections of diaphyses of os metacarpale III et IV are $29 \mathrm{~mm}$ long and $7 \mathrm{~mm}$ wide, those of os metacarpale III et IV are $30 \mathrm{~mm}$ long and $6 \mathrm{~mm}$ wide. They are still separated by a thin, continuous connective strip. There are distinct medullar cavities. Ossification centres 
appear in distal epiphyses. In os metacarpale III et IV they are $3 \mathrm{~mm}$ in cross-section, in os metatarsale III et IV $1 \mathrm{~mm}$ only.

Fetus CRL $=325 \mathrm{~mm}$, age about 140 DO, W $=1540 \mathrm{~g}$, CS 10 (No. 123/10): The diaphyses of os metacarpale III et IV are ossified in a section $24 \mathrm{~mm}$ long and $7 \mathrm{~mm}$ wide, those of os metatarsale III et IV are $29 \mathrm{~mm}$ long and $6 \mathrm{~mm}$ wide. The connective dissepiment between the ossified bones is more distinct proximally and distally. The epiphyses are cartilaginous.

Fetus CRL $=340 \mathrm{~mm}$, age about $147 \mathrm{DO}, \mathrm{W}=2260 \mathrm{~g}, \mathrm{CS} 10$ (No. 125): The total length of the rudimentary skeleton of os metacarpale III et IV is $48 \mathrm{~mm}$, that of os metatarsale III et IV is $54 \mathrm{~mm}$. The ossified parts of the diaphyses in os metacarpale III et IV are $33 \mathrm{~mm}$ long and $8 \mathrm{~mm}$ wide (Plate I, Fig. 2), those of os metatarsale III et IV are $37 \mathrm{~mm}$ long and 7 $\mathrm{mm}$ wide. There is a thin, $0.5 \mathrm{~mm}$ wide connective strip between the two bones. No onset of ossification can be observed in the epiphyses.

Fetus CRL $=360 \mathrm{~mm}$, age about $152 \mathrm{DO}, \mathrm{W}=2820 \mathrm{~g}, \mathrm{CS} 10$ (No. 129): The total length of the rudimentary skeleton of os metacarpale III et IV is $51 \mathrm{~mm}$, the ossified sections of the diaphyses are $35 \mathrm{~mm}$ long and $10 \mathrm{~mm}$ wide. The skeleton rudiment of os metatarsale III et IV is $58 \mathrm{~mm}$ in total length and $9 \mathrm{~mm}$ in width. There is a connective strip, $0.5 \mathrm{~mm}$ wide, between the ossified sections. The epiphyses are cartilaginous.

Fetus CRL $=600 \mathrm{~mm}$, age about $210 \mathrm{DO}, \mathrm{W}=14000 \mathrm{~g}$, CS 11 (no number): The total length of the rudimentary skeleton of os metacarpale III et IV is $112 \mathrm{~mm}$, the rudimentary diaphyses are $94 \mathrm{~mm}$ long, their ossified sections are $88 \mathrm{~mm}$ long and $17 \mathrm{~mm}$ wide. The skeleton rudiment of os metatarsale III et IV is $127 \mathrm{~mm}$ in total length, the rudimentary diaphyses are $108 \mathrm{~mm}$ long and their ossified sections are $103 \mathrm{~mm}$ long and $16 \mathrm{~mm}$ wide (Plate II, Fig. 5). The connective dissepiment between the bones is very thin, slightly widened proximally and distally. Ossification also takes place in epiphyses. The epiphysal rudiments, $18 \mathrm{~mm}$ in length, of os metacarpale III et IV contain distinct ossification centres of bone tissue, $12 \mathrm{~mm}$ in cross-section. The epiphysal rudiments, $19 \mathrm{~mm}$ in length, of os metatarsalis III et IV contain ossifications centres $11 \mathrm{~mm}$ in cross-section.

Fetus CRL $=820 \mathrm{~mm}$, age about $250 \mathrm{DO}, \mathrm{W}=25000 \mathrm{~g}$, CS 11 (no number): The total length of the rudimentary skeleton of os metacarpale III et IV is $147 \mathrm{~mm}$ long, the rudimentary diaphysis is $120 \mathrm{~mm}$ long. Its ossified part is $118 \mathrm{~mm}$ long and $18 \mathrm{~mm}$ wide (Plate II, Fig. 6). Medullar cavities are separated by an osseous dissepiment, a vestige of the connective strip being still present in the distal part. The rudimentary epiphyses are $27 \mathrm{~mm}$, their ossified sections are $24 \mathrm{~mm}$ long. The total length of the rudimentary os metatarsale III et IV is $160 \mathrm{~mm}$, the diaphysis is $134 \mathrm{~mm}$ long. Its ossified part is $132 \mathrm{~mm}$ long and $17 \mathrm{~mm}$ wide. Here, too, the medullar cavities are separated by an osseous dissepiment with a vestigial connective strip in the distal part. The rudimentary epiphyses are $26 \mathrm{~mm}$, their ossified parts are $23 \mathrm{~mm}$ long.

We demonstrated that the synostotic fusion of bones III and IV in both the metacarpus and the metatarsus will take place in the 9th month of intrauterine development of the fetus. Hence, the two bones cannot be separated after parturition.

\section{Discussion}

We have taken it for necessary to verify and compare the data provided by various authors (Rosenberg 1873; Mettam 1895; Petersen 1922; Küpfer and Schinz 1923; Regli 1963; Gjesdal 1969, and others) on the process of metapodium ossification. Our own comparable data were obtained from 10 fetuses from 68 to $820 \mathrm{~mm} \mathrm{CRL}$, at estimated ages from 60 to 250 day DO. Their metapodia were stained with alizarin red (Červený 1979). We found no essential differences from the data reported by the above authors.

Petersen (1922) found the onset of ossification in a fetus CRL $66 \mathrm{~mm}$, which corresponds to the age around 66 days. Küpfer and Schinz (1923) place the onset of ossification of the diaphyses of metapodia III and IV at the $9^{\text {th }}$ week of ontogeny (57-63 
days), and Gjesdal (1969) provided x-ray evidence of the beginning ossification of metapodia III and IV in fetuses of various cattle breeds at the age of 61-65 DO. On the basis of his material and measurements, Regli (1963) states that the metapodia begin ossifying on the $68^{\text {th }}$ day of ontogeny at the latest. At first the ossified sections are equal in length -2 and $3 \mathrm{~mm}$ - in the metacarpals and metatarsals, which situation persists until 80 DO. In our material we found, in a fetus $121 \mathrm{~mm} \mathrm{CRL}$, estimated age $80 \mathrm{DO}$, ossified sections $9 \mathrm{~mm}$ long in the cartilaginous rudiments of diaphyses of ossa metacarpalia III et IV as well as ossa metatarsalia III. et IV. In all cases examined, the process took place in CS 7, in fetuses CRL 80-120 mm, and at the age of 75-90 DO.

Henceforward the lengths of the ossified sections begin to differ in the metacarpals from those in the metatarsals. They are shorter in the metacarpals, this differences increasing in the course of intrauterine development (Regli 1.c.; Gjesdal 1.c.). At first the differences are $1 \mathrm{~mm}$, as found in fetuses CRL 150-180 mm, at 85-100 days of estimated age, when the ossified sections are 8-12 mm long in the metacarpals, as compared to those 9-13 $\mathrm{mm}$ long in the metatarsals. In our material, the ossified part of the metacarpus of a fetus CRL 173 was $12 \mathrm{~mm}$ long and that of the metatarsus $13 \mathrm{~mm}$ long.

In fetuses 200-230 mm CRL and estimated age EA 101-115 DO the difference increases to $2 \mathrm{~mm}$ (Regli 1.c., Gjesdal 1.c.). Fetus $222 \mathrm{~mm} \mathrm{CRL} \mathrm{in} \mathrm{our} \mathrm{material} \mathrm{shows} \mathrm{ossified}$ sections $18 \mathrm{~mm}$ (metacarpals) and $20 \mathrm{~mm}$ (metatarsals) in length. In this fetus it is possible to observe the development of medullar cavities. In all fetuses the distal epiphyses are cartilaginous and the rudimental bones are still independent. These observations agree with the literary data, and we can include all of them in the comparable stage (CS) 9.

In the fetus CRL $270 \mathrm{~mm}$, weighing $1092 \mathrm{~g}$ (whose age was estimated from its CRL and weight at 140 DO), the ossified sections of diaphyses in os metacarpale III et IV are $29 \mathrm{~mm}$ long, and in os metatarsale III et IV they are $30 \mathrm{~mm}$ long. Medullar cavities are distinct. Ossification centres appear in the distal epiphyses. In os metacarpale III et IV they are $3 \mathrm{~mm}$ in cross-section, in os metatarsale III et IV one mm only.

The next group comprises fetuses 300-360 mm CRL, estimated age 140-180 DO. The differences in the length of the ossified sections increase to $3-6 \mathrm{~mm}$ (Gjes dal 1.c.). The ossified sections of metacarpal diaphyses are 23-24 mm (Gje sdal 1.c.) or 23-26 mm (Regli l.c.) long, in our material 24-35 mm long. The ossified sections of the metatarsals are 26-30 $\mathrm{mm}$ (Gjesdal 1.c.) or 27-30 mm (Regli 1.c.) long, in our material 29-40 mm long.

Besides the lengths of the ossified sections, we also measured the total width of the two metapodia roughly in the middle of their length. In all cases examined the width of os metacarpale III et IV was wider by $1 \mathrm{~mm}$ than that of os metatarsale III et IV. We included these fetuses in CS 10 .

The hitherto literature data can be supplemented by our observations in older fetuses 600 $\mathrm{mm}$ and $820 \mathrm{~mm}$ in CRL. In the younger fetus (600 $\mathrm{mm} \mathrm{CRL}$, age about $220 \mathrm{DO}$ ) the ossified sections of the metacarpal diaphyses are $88 \mathrm{~mm}$ long and $17 \mathrm{~mm}$ wide. The ossified metatarsal diaphyses are $108 \mathrm{~mm}$ long and $16 \mathrm{~mm}$ wide; the difference in length is $20 \mathrm{~mm}$, in width one $\mathrm{mm}$. In the case of the older fetus ( $820 \mathrm{~mm} \mathrm{CRL}$, age about $260 \mathrm{OD}$ ) the total length of the rudimentary skeleton of os metacarpale III et IV is $147 \mathrm{~mm}$ and that of the rudimentary diaphysis is $120 \mathrm{~mm}$. Its ossified part is $118 \mathrm{~mm}$ long and $18 \mathrm{~mm}$ wide. The rudimentary epiphyses are $27 \mathrm{~mm}$ long, their ossified sections $24 \mathrm{~mm}$, indicating that the ossified bone parts are $5 \mathrm{~mm}$ shorter than the total length of the rudiment. Its cartilaginous character is present only in the place of the growing epiphysal cartilage and on the surface of both joints. The rudimentary os metatarsale III et IV. is $160 \mathrm{~mm}$ in total length, the diaphysis in $134 \mathrm{~mm}$ long, its ossified part $132 \mathrm{~mm}$ long and $17 \mathrm{~mm}$ wide. The rudimentary epiphyses are $26 \mathrm{~mm}$ long, their ossified parts $23 \mathrm{~mm}$ long. Even in this case the ossified parts are $5 \mathrm{~mm}$ shorter $(155 \mathrm{~mm})$, their total length of $160 \mathrm{~mm}$ being completed by the growing cartilage plus the proximal and distal joint cartilages. 
In the latter two fetuses also the distal epiphyses show the onset of ossification: the ossification centres found in the younger of the two were 12 and $11 \mathrm{~mm}$ in cross-section; in the older one, 23 and $24 \mathrm{~mm}$ in cross-section. Küpfer and Schinz (1923), Regli (1963) and $\mathrm{Gjes}$ dal (1969) also place the onset of ossification of the distal epiphyses between 180 and 210 days, i.e., in the course of the $7^{\text {th }}$ month of intrauterine development. We included these fetuses in CS 11.

Our fetus CRL 270 mm, weighing $1092 \mathrm{~g}$ (No. 120/10), stands beyond the scope of this time scheme. In this fetus we found ossification centres present even in the epiphyses of the metacarpal as well as metatarsal bone rudiments. The size of this fetus corresponds with the age of about 140 DO i.e. 5th month of intrauterine development (Evans and Sack 1973; Šterrba 1979), that is, CS 10. The epiphyses should not begin to be ossified before the end of the $7^{\text {th }}$ month of intrauterine development, both in the sense of the above authors and our own observations. Upon closer examination of the degree of development of that fetus, we also found characters (short hairs in the proximal parts of metapodia) that correspond with the age of 195-200 DO, i.e., are close to the characters defining CS 11. We refrain from classifying this anomaly without a detailed analysis, and exclude this case from our evaluation, as the differences in size, weight and development of external characters lie outside the normal variation range and thus cannot be considered to be normal. However, we have included this case for the sake of interest and also to underline the necessity of considering the overall character of material examined, in this case the degree of development of a fetus. Employing the comparable stages (CS) makes it possible to avoid erroneous interpretation of observations.

The epiphysis fuses with the diaphysis at the age of 2-2.5 years when the cartilaginous epiphysal plate becomes ossified, thus stopping the longitudinal growth of the metapodia (Kolda 1936). Červený (1980), employing the x-ray method and alizarin red staining, found remains of epiphysal cartilage in the metapodium of a bull 20 months of age. Červený et al. (1987) studied the changes in bone structure in the epiphysal-diaphysal fusion in years following parturition.

Küpfer and Schinz (1923) studied the process of bone fusion in x-ray images. They found the rudimentary diaphyses of metapodia III and IV to be independent from the onset of ossification, i.e. from 9 weeks of age (approximately $65 \mathrm{DO}$ at CRL $82 \mathrm{~mm}$ ) until 6 months of intrauterine development (i.e. up to $180 \mathrm{DO}$ and $520 \mathrm{~mm} \mathrm{CRL}$ ). Our observations can supplement the data by stating that at that time the bones are separated by a thin stripe of connective tissue which gradually vanishes later. Furthermore, Küpfer and Schinz (1923) state that in fetuses 570 and $580 \mathrm{~mm}$ CRL, of the same age as above, the ossified diaphyses are in close contact, the same as those in the fetus CRL $730 \mathrm{~mm}$, i.e. also at 7 months of intrauterine development, when the distal epiphyses begin to become ossified. Regli (1963) observed the onset of fusion of bones of metapodia III and IV between days 185 and 195, advancing in the proximal-distal direction. In his Figs. 2a and 2b, the author demonstrates macerated metacarpi of fetuses younger than $180 \mathrm{DO}$, with metacarpus III and IV still independent. At 200 days the fusion was in full swing, and its completion is placed around 210 DO. Contrary to the data presented by Regli (1.c.), it is our opinion that the fusion is completed still later, somewhere between 225 and $230 \mathrm{DO}$. We are unable to confirm the observation reported by Kolda (1936), stating that the two bones can still be separated in newborns, and we tend to consider it dubious.

\section{References}

ČERVENÝ, Č 1971: Notes on methods of studying the structure and ossification of the ethmoid bone. Acta Vet Brno 40: 361-365

ČERVENÝ, Č 1979: The use of differentiation staining of bone on anatomic preparations. Acta Vet Brno 48: 3-7 
ČERVENÝ, Č 1980: Epiphysodiaphyseal growth zones in metapodium and autopodium of cattle in postnatal ontogenesis. Acta Vet Brno 49: 11-30

ČERVENÝ, Č 1983: Ossification and development of the ossa sesamoidea phalangis proximalis in cattle. Acta Vet Brno 52: 27-38

ČERVENÝ, Č 1985: Anatomical characteristics on the ossa sesamoidea phalangis proximalis in cattle.(Bos primigenius f. taurus Linné 1758). Acta Vet Brno 54: 3-22

ČERVENÝ, Č 1985: Osteometry of the ossa sesamoidea phalangis proximalis in cattle (Bos primigenius f. taurus Linné 1758). Acta Vet Brno 54: 119-128

ČERVENÝ, Č, LUKÁS̆, J, STINGLOVÁ, H 1987: Roentgenograph of epiphysodiaphyseal zone of metapodium in cattle as related to age. Acta Vet Brno 56: 251-260

ČERVENÝ, Č, PÁRAL, V 1994: Ossification of ossa sesamoidea distalia in cattle. Acta Vet Brno 63: 89-93

EVANS, HE, SACK, WO 1973: Prenatal development of of domestic and laboratory mammals. Anat Histol Embryol 2: 11-45

GJESDAL, F 1969: Age determination of bovine fetuses. Acta Vet Scand 10: 197-218

KOLDA, J 1936: Srovnávací anatomie zviŕrat domácích se zřetelem k anatomii člověka. I. část obecná , II. Nauka o kostech a chrupavkách. Novina, Brno, pp. 914

KÜPFER, M, SCHINZ, HR 1923: Beiträge zur Kenntnis der Skelettbildung bei domestizierten Säugetieren auf Grund röntgenologischer Untersuchungen. Neue Denkschr Schweiz Naturf Ges 59: 133

MARTIN, P 1912: Lehrbuch der Anatomie der Haustiere. I.Band. Verlag von Schickhardt \& Ebner, Stuttgart, pp.811

METTAM, AE 1895: The rudimentary metacarpal and metatarsal bones of the domestic ruminants. J Anat 29: 244253

PÁRAL, V, MÍŠEK, I 1994: Dynamics of mineralization in different parts of long bone of the bovine fetus. Func Develop Morphol 4: 233-235

PETERSEN, G 1922: Untersuchungen über das Fussskelett des Rindes. Morph Jb 51: 291-337

REGLI, K 1963: Beitrag zur Altersbestimmung von Feten des Simmentaler und Freiburger Fleckviehrindes insbesondere auf Grund von Messungen an Gliedmassenknochen. Inaug. - Diss Vet Med Fak Univ Zürich, P.G.Keller, Winterthur, pp. 67

ROSENBERG, A 1873: Über die Entwickelung des Extremitäten-Skeletts bei einigen durch Reductionen ihrer Gliedmassen charakterisirten Wirbelthieren. Zf wiss Zool 23: 116-170

ŠTĚRBA, O 1979: Prenatal growth of certain artiodactyls. Folia Zool 28: 321 -328

ŠTĚRBA, O 1995: Staging and ageing of mammalian embryos and fetuses. Acta Vet Brno 64: 83-89 


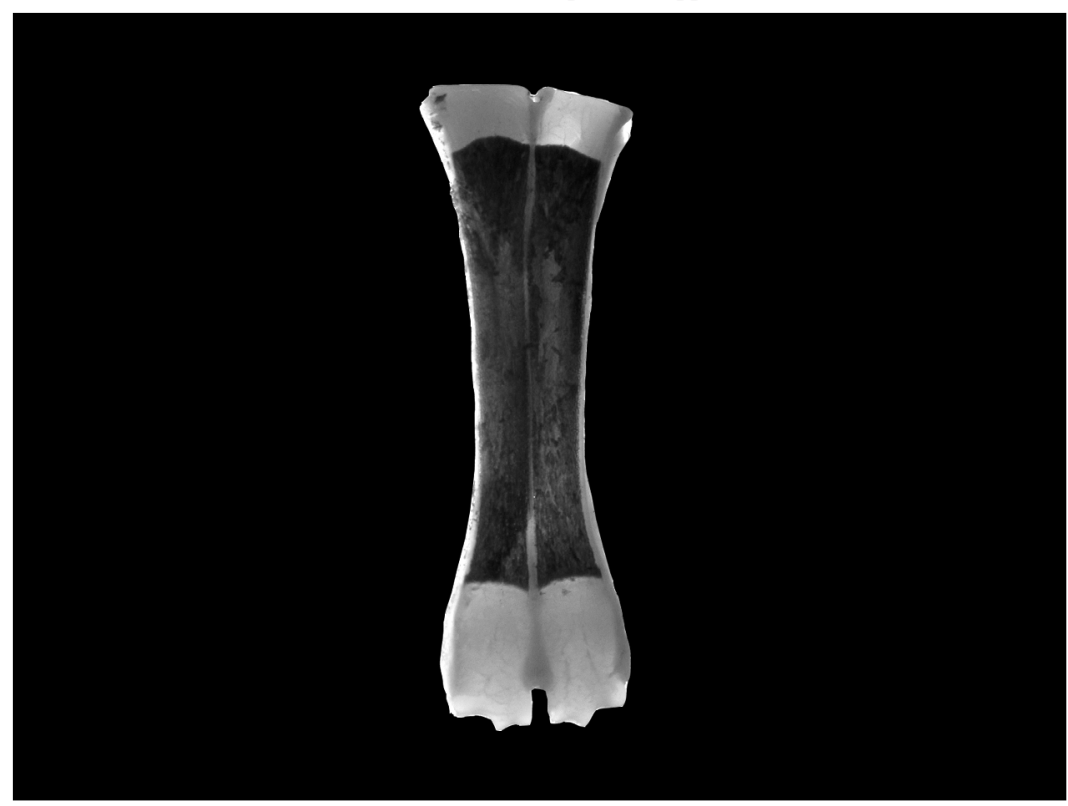

Fig.3. Longitudinal section through the metacarpus (length of the ossified parts of diaphyses $=9 \mathrm{~mm}$ ) and fingers of a fetus, CRL $=120 \mathrm{~mm}$, age about $80 \mathrm{DO}, \mathrm{W}=76 \mathrm{~g}, \mathrm{CS}$ 8. Stained with alizarin red.

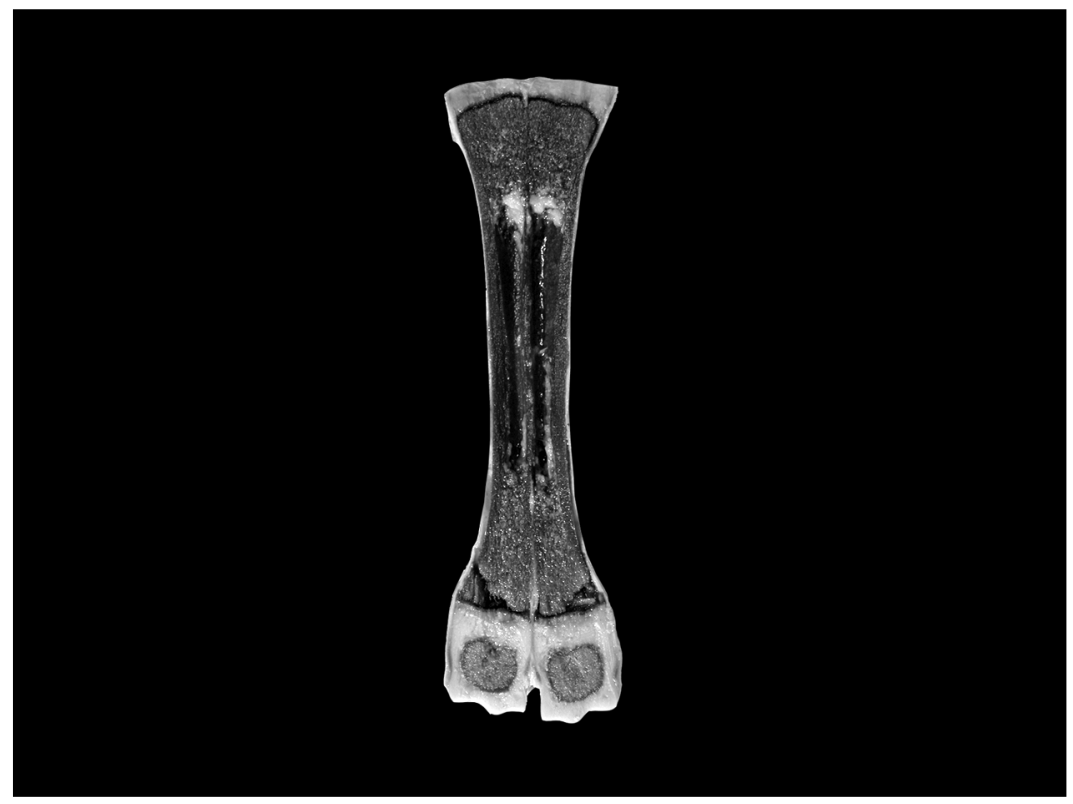

Fig. 4. Longitudinal section through the metacarpus (length $=48 \mathrm{~mm}$ ) of a fetus, $\mathrm{CRL}=340 \mathrm{~mm}$, age about $147 \mathrm{DO}, \mathrm{W}=2260 \mathrm{~g}, \mathrm{CS} 10$. Stained with alizarin red. 


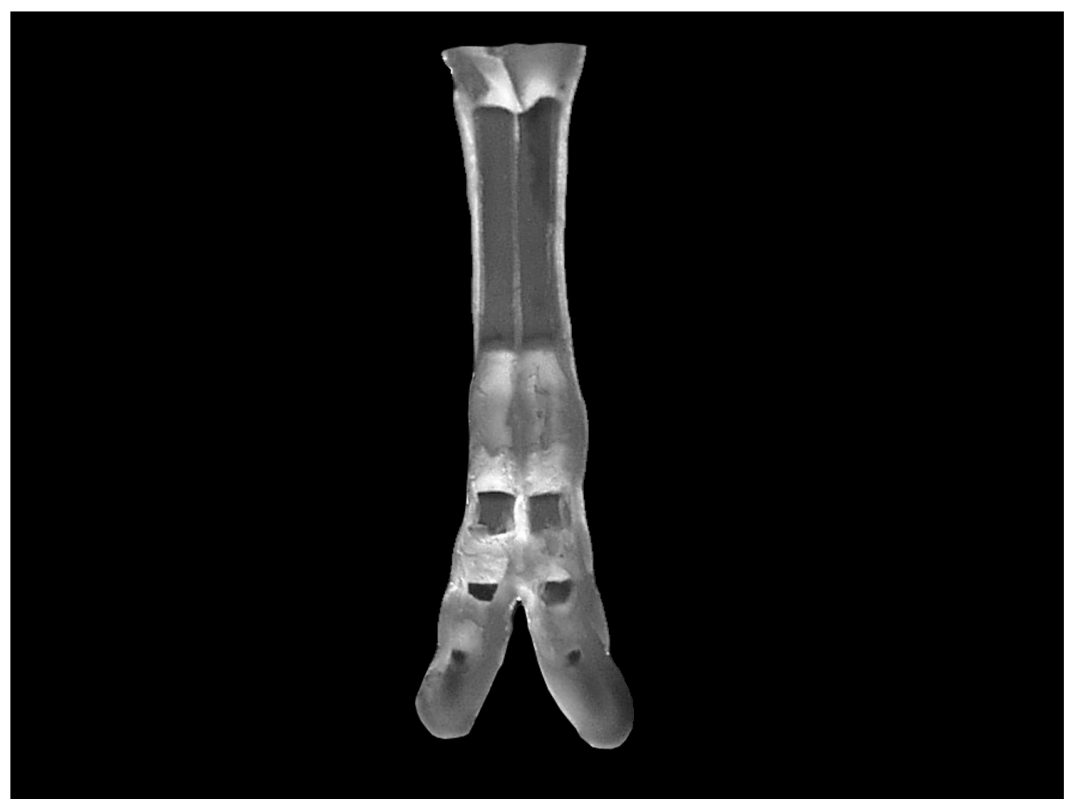

Fig. 5. Longitudinal section through the metatarsus (length $=127 \mathrm{~mm}$ ) of a fetus, CRL $=600 \mathrm{~mm}$, age about $210 \mathrm{DO}, \mathrm{W}=14000 \mathrm{~g}, \mathrm{CS} 11$. Stained with alizarin red.

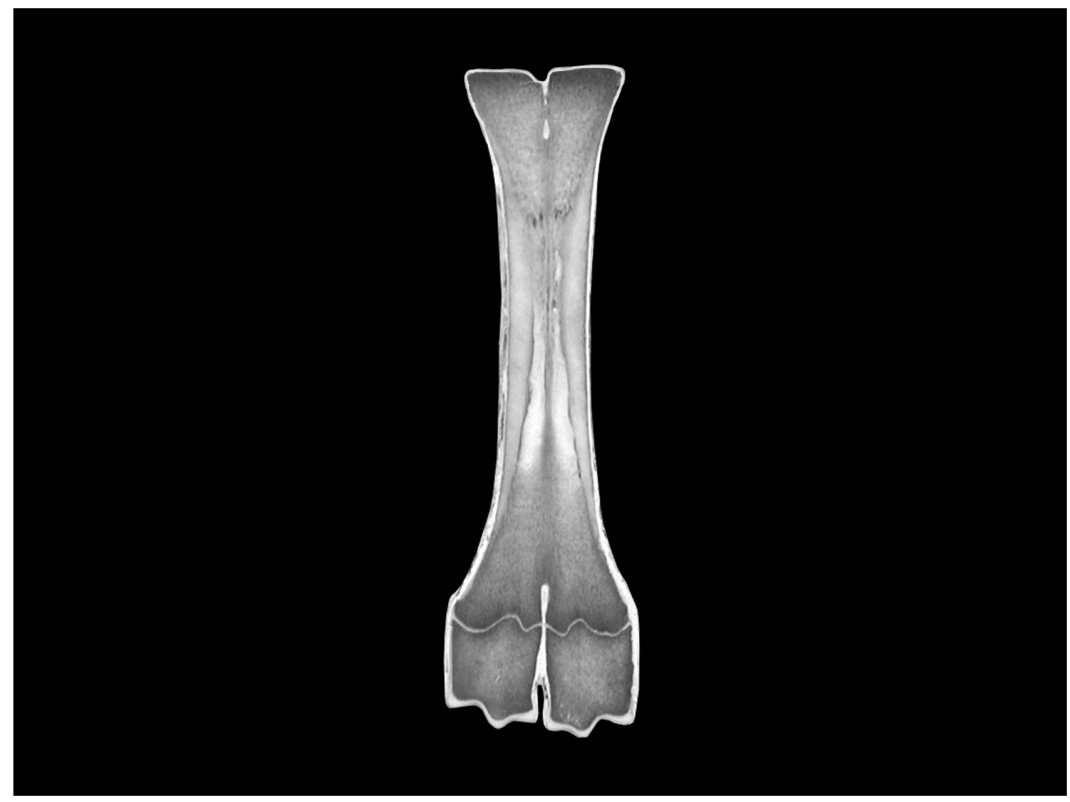

Fig. 6. Longitudinal section through the metacarpus (length $=147 \mathrm{~mm}$ ) of a fetus, CRL $=820 \mathrm{~mm}$, age about $250 \mathrm{DO}, \mathrm{W}=25000 \mathrm{~g}, \mathrm{CS} 11$. Stained with alizarin red. 